\author{
Review Article \\ www.ijrap.net (ISSN:2229-3566)
}

\title{
ROLE OF KOSHTHA AND AGNI IN PANCHAKARMA: A CRITICAL REVIEW
}

S Triveni Manju ${ }^{1 *}$, Vinay Kumar $\mathrm{K} \mathrm{N}^{2}$

${ }^{1}$ PG Scholar, Department of PG Studies in Panchakarma, Sri Kalabyraveshwara Swamy Ayurvedic Medical

College and Research Centre, Bangalore, Karnataka, India

${ }^{2}$ Professor and HOD, Department of PG Studies in Panchakarma, Sri Kalabyraveshwara Swamy Ayurvedic Medical College and Research Centre, Bangalore, Karnataka, India

Received on: 31/12/20 Accepted on: 18/02/21

\author{
*Corresponding author \\ E-mail: trivenimanju88@gmail.com
}

DOI: $10.7897 / 2277-4343.120129$

\begin{abstract}
Ayurveda, the ancient science of life originated in India more than 5,000 years ago and is often called the "Mother of All Healing". Panchakarma is considered to be the most eminent branch of Ayurveda, as the name suggests it is a 'five-step' process for a complete detoxifying and rejuvenating therapy. Every individual is unique in Prakruti, Dosha, Agni, Koshtha and such other factors. So before administrating any Panchakarma procedure it is must to assess the Agni and Koshtha of the person. Agni and Koshtha role can be explained in 3 aspects- i.e., Poorva Karma (Deepana - Pachana, Snehana and Swedana), Pradhana Karma (Vamana karma, Virechana Karma, Basti Karma and Nasya) and Paschat Karma (Samsarjana krama). An attempt is made in the article to highlight the importance of Agni and Koshtha in all the aspects with respect to Panchakarma.
\end{abstract}

Keyword: Panchakarma, Agni, Koshtha, Poorvakarma, Pradhana Karma, Paschat Karma.

\section{INTRODUCTION}

Panchakarma presents a unique approach of Ayurveda with specially designed five procedures of internal purification of the body through the nearest possible route.

In Rasa Shastra, Shodhana is a process that is employed during the pharmaceutical processing either to detoxify, purify or to potentiate the efficacy of the raw materials. In the same way in Panchakarma, the Shodhana process is employed to purify the body and removal of the toxic elements from the body allowing the permanent healing of tissues and channels. Koshtha, Agni and Bala are the important assessment factor in Panchakarma.

\section{Agni}

Agni is termed as Vaishwanara as it takes the person from mrityuloka to swargaloka. It is an important factor and is equivalent to prana, is one among dashapranaayatana. The concept of tejas (Agni) is implicit in the rajas of Sankhya system, Rajas, stands for kinetic energy of the universe. Thus, for every motion Agni is essential and this motion, in turn produces Agni.

\section{Agniushmaniyatva jagat ${ }^{1}$}

Ayurveda considers that Dehagni is the cause of life, complexion, strength, health, nourishment, oja, tejas and prana. ${ }^{2}$ When Agni stops functioning, the individual dies and if Agni functions normally the individual can lead healthy life. ${ }^{3}$

Agni in Ayurveda is reflected in the concept of Pitta. The term Pitta is derived from the root 'tap'- to heat or to burn. This term has three meanings viz.

- Tapa aishwarya- factor which responsible to make one achieve the eight kind of benefits
- Tapa daha - act of burning of the nutrition consumed

- Tapa santape - the generation of heat

Pitta is same as Agni, since it performs fire like actions i.e., Paka which refers to Pachana, dahana, parinama, pravrtti, prakasana, ranjana, or varnakara and prabhakara. Not in very aspects these 2 are same - Agni has opposite gunas when comparing to Pitta. ${ }^{4}$

The seat of Agni is Grahani ${ }^{5}$, so the strength of the Grahani is from Agni itself, and the strength of Agni is from Grahani. When the Agni undergoes vitiation, Grahani also gets vitiated and produces diseases.

\section{Koshtha}

Koshtha is the nature of bowel habit, which originates as an entity of Prakruti at the time of conception and the anatomical entity, the space or the hollowness of the body includes all the organs of abdominal and thoracic cavities ${ }^{6}$ which represents motility of the intestines and movement of food and faecal matter in the alimentary canal and elimination of stool. Acharya Charaka also spoken of Koshtha as Mahasrotas. ${ }^{7}$ Koshtha assessment plays a Pivotal role in the attainment of Samyak Shodhana.

According to Charaka - 'matra kalashraya yuktihi', the matra and kala are to be taken as the main keys for implication of Agni and Koshtha as parameters respectively.

\section{Role of Koshtha and Agni in Poorvakarma}

Poorvakarma is the first set of action which is a combination of external and internal procedures and before the actual procedure of purification begins, there is a need to prepare the body with prescribed methods to encourage it to let go of the toxins. The main cause of maximum of diseases is ama or undigested toxins that get formed in the system due to external factors and spread 
to different parts of the body. Through Poorvakarma these toxins are channelized and collected for easy removal at Pradhana karma stage.

\section{In Deepana and Pachana}

Deepana means kindling or igniting of Agni but it does not digest the $a m a^{8}$. Deepana drugs are Agni and Vayu bhuta dominanceit increases the stimulation of jatharagni and so increases the appetite and improves abhyavaharana shakti. It makes the body ready to accept the drugs.

Pachana causes the digestion of ama and used as a poorvakarma before shodhana. It increases the jarana shakti. If Snehana is done in amayukta condition, it leads to the destruction of sanja and even death and if samshodhana medicine is taken in the condition of ajeerna, it will lead to vibandha and glani. On the contrary, it will produce samyak shodhana in the absence of ama. ${ }^{9}$

\section{In Snehapana}

Sneha Prayoga without the consideration of Agni is irrational. ${ }^{10}$ When the administration kala of shodhananga snehapana is considered it is been mentioned that it should be given in early morning hours when the earlier food is digested and Agni should be in optimum level not very strong. There are different concepts explained by Acharyas in the context of Snehapana and relation with Koshtha and Agni. Ghrita administrated along with kshara and Lavana and then Swedana followed Virechana is employed in Manda Agni and Krura Koshtha persons. ${ }^{11}$ Sneha taken by a person having dominance of pitta in Grahani and having strong digestive power gets digested quickly by the virtue of power of Agni. $^{12}$

Acharya Vagbhata has mentioned about Hrasiyasi Matra (test dose). Hrasiyasi Matra is the quantity of Sneha which digests within one Yama and this can be used as trial dose when the Agni is unknown.

During Snehapana, Agni Vriddhi (increase in digestive function) is expected. All though Sneha has opposite character than Agni, when it gets digested, it serves as a fuel and kindles the Agni. This Agni has more power to digest even more quantity of Sneha. Therefore, while calibrating Agnibala, quantity of Sneha and duration for digestion plays important role. Agnibala and digestive period are inversely proportional i.e., as Agnibala increases, the digestion period is bound to decrease, even when the same dose is administered or when the dose is increased.

For the administration and fixation of sneha, Koshtha should be assessed.

1. Mridu koshtha - 3 days should be given $\rightarrow$ uttama matra sneha should not be given in this type because it will cause Agnimandhya

2. Krura koshtha- 7 days should be given $\rightarrow$ if madhyama or hrshva matra is given in krura koshtha; sneha is not rational because this dose does not cause doshotklesha. ${ }^{13}$

3. In Sadhyo sneha- Koshtha should be considered Mridu and as their will be Swayam utklishta dosha, Agni doesn't have upper hand; however, administration of shodhana aushadha after Sadhyo sneha is after assessing Agni and Koshtha.

\section{In Swedana}

Swedana helps in dosha Dravatva and Agni Deepana. ${ }^{14}$ Ushna and tikshna properties of Swedana karma help in digestion of ama dosha, which results in stimulation of all the 13 types of Agni. In case of Agni Mandhya, Swedana should not be performed.

\section{In Bahirparimarjana chikitsa}

Bhrajaka pitta plays a vital role in absorption of drug through skin i.e., in Bahirparimarjana chikitsa ${ }^{15}$. When we see the mode of action of Utsadana and Udgharshana, it causes dilatation of Siramukha and stimulating the Agni situated in the skin. ${ }^{16}$

\section{Role of Koshtha and Agni in Vamana}

The gunas of Vamana Aushadhi's includes agni and vayu mahabhuta predominant and possess the Vyavayi, ushna and tikshna guna which suggests that the drug shows Prabhava before digested to jatharagni. Improper or perversion of procedures like Vamana, which leads to vitiation of Agni. Acharya Sushruta quotes that by looking at the vyadhi bala, purusha bala and agni bala dosage should be fixed, if person given more than agni bala it leads to ajeerna and vishtambha and does Pachana. There are 3 types of Koshtha in relation to Vamana explained by Arundatta. If shleshma adikatwam is there it is mridutvam so less dose of Vamana aushadhi is enough, if shleshma madhyatwam it is madhyatwam and if shleshma hinatwam is there it is kruratwam. So, the treatment should be planned by considering all this.

\section{Role of Koshtha and Agni in Virechana}

Proper assessment of Agni and Koshtha leads to Samyak Yogas of Virechana. Virechana drugs are administered after shleshma kala has passed and determining the Koshtha of the person. It is necessary to determine the nature of Koshtha viz Mridu, madhyama and krura koshtha for planning of Virechana karma as aushadha gets Pachyamana avastha in Virechana procedure. ${ }^{17}$ In krura koshtha, there will be Grahani ulbana anila and in Mridu koshtha, Udirna pitta- alpa kapha- grahani manda maruta will be there. If Virechana aushadhi is given in person of krura koshtha, the drugs get digested instead of purgation. So, for this condition Basti should be given before giving Virechana. ${ }^{18}$

In Mridu koshtha person, if ati tikshna aushadhi is given it will pass quickly without dosha properly eliminated. ${ }^{19}$ According to Sharangadhara Samhita, tikshna virechana should be given in krura Koshtha persons, Mridu virechana in Mridu Koshtha persons and madhyama virechana in madhyama Koshtha. Asamyak Virechana leads to Agni mandya and Samyak Virechana leads to Agni vriddhi.

Intervention of Agni in other types of Virechana-

- Anulomana-kritwa paka

- Sramsana-paktavyam yadi paktaiva

- Rechana-vipakwam yadapakwam

\section{Role of Koshtha and Agni in Basti}

When we see the guna of Niruha, it is said to be Agni vardhaka. Moreover, basti dravya doesn't come into the direct contact of the jatharagni but there is significant role of Agni and Koshtha in Basti karma as well as in samikshya bhava mentioning of Agni is there. $^{20}$

Acharya Chakrapani mentioned the concept like 'pakwashayooplepaka bahirnisratineya ushmna pachti'21 in Anuvasana basti context. Acharya Chakrapani had quoted about Soshyamana Agni which is present in the Pakwashaya. 
Some concepts for supporting that agni and koshtha have a role in Basti Karma have been mentioned. The contraindication of Niruha basti includes ajeerna and manda agni condition and Anuvasana basti in manda agni and guru koshtha persons and if Anuvasna basti is administered in these persons it further reduces the power of digestion. Indication of Anuvasna basti includes those having tikshna agni, ruksha and kevala vata rogas ${ }^{22}$ because these persons absorb sneha quickly just as sand filter the water. If we see the indication of Matra Basti, it is been told in alpa agni person and Madhutailika Basti in Mridu koshtha person. If the Anuvasna Basti is given continuously it will destroy the Agni and aggravate the dosha. If excessively sharp and hot recipe of Basti given in Mridu koshtha it will cause symptoms of atiyoga of Vamana and Virechana. ${ }^{23}$ If in krura koshtha and Maha dosha person, alpa virya aushadhi is given causes margavarodha thus obstructs vata. ${ }^{24}$ If in krura koshtha and durbala person, recipe which is cold and less in quantity is given it will cause avarana and related symptoms. ${ }^{25}$ If in Mridu koshtha person, ruksha, tikshna, bahu matra aushadhi is given causes

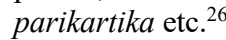

\section{Role of Koshtha and Agni in Nasya}

There is no direct relation of koshtha and agni in Nasya but because of the agni only the absorption of Nasya aushadhi takes place. In Ajeerna condition, if Nasya is given it will cause occlusion of circulation of dosha moving upward and causes Shwasa, Kasa, Chardi. So Deepana and Pachana before administration of Nasya should be done. There is limited role of Koshtha in Nasya but in Pratishsyaya considering the Koshtha, Nasya is given.

In Nasya, Agni and Koshtha have limited implication, however it is said that Nasya should be preceded by Shodhana and Abhyanga and Sweda done as poorvakarma in which all Agni and Koshtha plays a vital role.

\section{Role of Koshtha and Agni in Pashchat karma}

The Pashchat karma of Shodhana includes Samsarjana krama because after Shodhana due to the elimination of the doshas from the body, Agni becomes weak, so Peyadi Samsarjana krama should be followed. Just like too many fire woods when placed on the fire diminishes the fire, similarly guru anna further deranges the already weakened Agni. Whereas laghu meals in sufficient quantity and on appropriate time will accentuate the Agni just like the way small twigs and fire woods would aid proper burning of the fire. Similarly weakened digestive fire gets kindle by Samsarjana krama gradually and becomes capable of digesting even heaviest meal.

\section{DISCUSSION}

Koshtha and Agni are the important concepts which are useful in different aspects of treatment, so understanding the relation of Prakruti - agni - koshtha with reference to Shodhana procedure is very important.

The types of koshtha are related to the presence of sara guna like in Pittaja prakriti due to the presence of extra sara guna leads to Mridu koshtha i.e., kseerena virechyati. When we consider the 3 stages of Shodhana; in Snehapana, Virechana and Samsarjana krama only, there is direct contact of aushadhi to koshtha and agni and leads to the digestion of drugs but role of koshtha and agni doesn't limited in these only, it extends and indirectly related to all the other procedures of Panchakarma. As if we see Vamana drugs are not undergoing digestion but still there is hampering of Agni but less than that of Virechana. This can be understood under different heading - first one is the magnitude of the drug contact. The Vamana drugs are just in the level of Amashaya but in Virechana, drugs have to travel whole through the GI tract. As the contact time of Virechana aushadhi is more than that in Vamana so the Agni hampering is more in the Virechana. Second one is the time taken for the completion of the entire procedure which is less in the Vamana when comparing to Virechana and so Agni is less hampered. Koshtha and Agni have equal importance in Basti and Nasya for the absorption of drug and then showing its effects.

Generally, in Ayoga of Shodhana the Koshtha and Agni should be seen and next dose of aushadha should be administered. In Rikta koshtha and Mridu koshtha, ati tikshna aushadhi if given it will firstly cause the flow of mala, pitta and kapha and simultaneously rasaraktadi dhatu srava also is taken place leading to the ati yoga. If there is aparigynat koshtha, then Mridu koshtha and alpa Mridu aushadhi should be given. Impaired Agni is the root cause of all diseases, so proper care of koshtha and Agni should be taken.

\section{CONCLUSION}

Koshtha and Agni is the basic and important concept in Ayurveda. For the administration of drugs and also in every stage of Panchakarma, Koshtha and Agni play a key role. So, from the above, it can be concluded that there is significance role of Koshtha and Agni in Panchakarma, which has been misunderstood and misinterpreted and not used properly. It plays an important role in selection of the line of treatment of disease. If anyone administers without considering Koshtha and Agni, it leads to severe complications, even death may occur. So, it is obligatory to include Agni and Koshtha in the Panchakarma.

\section{REFERENCES}

1. Sushruta, Dalhana, Sushruta Samhita with Nibandha Sangraha and Nyayachandrika Panjika Commentary, Sutra Sthana 40:5, Reprint Edition, Chaukhamba Orientalia; 2019. p. 175.

2. Agnivesha, Charaka Samhita with Ayurveda Dipika commentary, Chikitsa sthana 15:3, Reprint edition, Chaukhambha Orientalia; 2011. p. 512.

3. Agnivesha, Charaka Samhita with Ayurveda Dipika commentary, Chikitsa sthana 15:4, Reprint edition, Chaukhambha Orientalia; 2011. p. 512.

4. Sushruta, Sushruta Samhita with Nibandha Sangraha, Nyayachandrika Commentary, Sutra Sthana 21:9, Reprint Edition, Chaukhambha Sanskrit Sansthan; 2017. p. 100.

5. Agnivesha, Charaka Samhita with Ayurveda Dipika commentary, Chikitsa Sthana 13:65, Reprint edition, Chaukhambha Orientalia; 2011. p. 517.

6. Sushruta, Sushruta Samhita with Nibandha Sangraha, Nyayachandrika Commentary, Chikitsa Sthana 2:12, Reprint Edition, Chaukhambha Sanskrit Sansthan; 2017. p. 409.

7. Agnivesha, Charaka Samhita with Ayurveda Dipika commentary, Sutra Sthana 11:48, Reprint edition, Chaukhambha Orientalia; 2011. p. 77.

8. Sharangadhara, Sharangadhara Samhita, Adhamalla's and Gudhartha Dipika, Sanskrit Commentary by Adhamalla and Kashirama, Prathama Khanda 4:1, Reprint Edition, Chaukhambha Surbharati Prakashana; 2012. p. 34.

9. Agnivesha, Charaka Samhita with Ayurveda Dipika commentary, Siddhi Sthana 6:14, Reprint edition, Chaukhambha Orientalia; 2011.p. 704.

10. Vagbhata, Ashtanga Hridaya with Arundatta and Hemadri commentary, Sutra sthana 16:18, Reprint edition, Chaukhambha Surbharati Prakashana; 2010. p. 246. 
11. Sushruta, Sushruta Samhita with Nibandha Sangraha, Nyayachandrika Commentary, Chikitsa Sthana 33:39, Reprint Edition, Chaukhambha Sanskrit Sansthan; 2017. p. 520.

12. Agnivesha, Charaka Samhita with Ayurveda Dipika commentary, Sutra Sthana 13:70-71, Reprint edition, Chaukhambha Orientalia; 2011. p. 85.

13. Agnivesha, Charaka Samhita with Ayurveda Dipika commentary, Sutra Sthana 13:65, Reprint edition, Chaukhambha Orientalia; 2011. p. 85.

14. Sushruta, Sushruta Samhita with Nibandha Sangraha, Nyayachandrika Commentary, Chikitsa Sthana 32:22, Reprint Edition, Chaukhambha Sanskrit Sansthan; 2017. p. 514.

15. Sushruta, Sushruta Samhita with Nibandha Sangraha, Nyayachandrika Commentary, Sutra Sthana 21:10, Reprint Edition, Chaukhambha Sanskrit Sansthan; 2017. p. 101.

16. Sushruta, Sushruta Samhita with Nibandha Sangraha, Nyayachandrika Commentary, Chikitsa Sthana 24:53, Reprint Edition, Chaukhambha Sanskrit Sansthan; 2017. p. 489.

17. Sushruta, Sushruta Samhita with Nibandha Sangraha, Nyayachandrika Commentary. Chikitsa Sthana 33:34, Reprint Edition, Chaukhambha Sanskrit Sansthan; 2017. p. 519.

18. Agnivesha, Charaka Samhita with Ayurveda Dipika commentary, Kalpa Sthana 12:79-80, Reprint edition, Chaukhambha Orientalia; 2011.p. 675.

19. Agnivesha, Charaka Samhita with Ayurveda Dipika commentary, Siddhi Sthana 6:45, Reprint edition, Chaukhambha Orientalia; 2011. p. 706.
20. Agnivesha, Charaka Samhita with Ayurveda Dipika commentary, Siddhi Sthana 3:6, Reprint edition, Chaukhambha Orientalia; 2011. p. 691.

21. Agnivesha, Charaka Samhita with Ayurveda Dipika commentary, Siddhi Sthana 4:42-47, Reprint edition, Chaukhambha Orientalia; 2019. p. 701.

22. Agnivesha, Charaka Samhita with Ayurveda Dipika commentary, Siddhi Sthana 2:19, Reprint edition, Chaukhambha Orientalia; 2019. p. 689.

23. Agnivesha, Charaka Samhita with Ayurveda Dipika commentary, Siddhi Sthana 7:12, Reprint edition, Chaukhambha Orientalia; 2019. p. 710.

24. Agnivesha, Charaka Samhita with Ayurveda Dipika commentary, Siddhi Sthana 7:21, Reprint edition, Chaukhambha Orientalia; 2019. p. 710.

25. Agnivesha, Charaka Samhita with Ayurveda Dipika commentary, Siddhi Sthana 7:43, Reprint edition, Chaukhambha Orientalia; 2019. p. 711.

26. Agnivesha, Charaka Samhita with Ayurveda Dipika commentary, Siddhi Sthana 7:54, Reprint edition, Chaukhambha Orientalia; 2019. p. 712.

\section{Cite this article as:}

S Triveni Manju and Vinay Kumar K N. Role of Koshtha and Agni in Panchakarma: A Critical Review. Int. J. Res. Ayurveda Pharm. 2021;12(1):129-132 http://dx.doi.org/10.7897/22774343.120129

Disclaimer: IJRAP is solely owned by Moksha Publishing House - A non-profit publishing house, dedicated to publishing quality research, while every effort has been taken to verify the accuracy of the content published in our Journal. IJRAP cannot accept any responsibility or liability for the site content and articles published. The views expressed in articles by our contributing authors are not necessarily those of IJRAP editor or editorial board members. 